\title{
Contraception
}

\section{Current state of the art}

Thirty years ago the United Kingdom Family Planning Association introduced combined contraceptive pills into its clinics. Before 1960 there had been no hormonal methods of contraception, and intrauterine devices were only just becoming available.' Most women in the United Kingdom relied on coitus interruptus, diaphragms (available only to married women), sheaths, the rhythm method, or luck. Today, three million women in the United Kingdom use the contraceptive pill-for young nulliparous women it is the most popular method of contraception (table). ${ }^{2}$

\section{Hormonal forms of contraception}

The first combined pill contained $150 \mu \mathrm{g}$ ethinyloestradiol and $10 \mathrm{mg}$ norethisterone. Modern pills usually contain between 20 and $35 \mu \mathrm{g}$ of ethinyloestradiol and, if norethisterone is used, only $0 \cdot 5-1 \cdot 5 \mathrm{mg}$ norethisterone. This reduction has occurred in stages as new health risks have emerged. The first of these was an increased risk of venous thromboembolism, ${ }^{3.5}$ which led to a reduction in the dose of oestrogen. In the late 1970s the risk of arterial disease was related to the dose of progestogens then in use, ${ }^{6}$ which was subsequently reduced. Early studies failed to take into account the effect of smoking, ${ }^{78}$ which considerably increases the risk of arterial disease ${ }^{9}$-an effect potentiated by the pill. ${ }^{10}$ Women who smoke should stop taking the pill by the age of 35 as the risks of cardiovascular disease then become unacceptably high." The most recent analyses, however, from the prospective studies of the Royal College of General Practitioners $^{12}$ and the Oxford Family Planning Association ${ }^{13}$ failed to find any effect on arterial disease in non-smokers; it must therefore be very small if not absent in this group. The fertility and maternal health drugs advisory committee of the Food and Drug Administration in the United States removed the upper age limit for use of the contraceptive pill by healthy non-smokers. ${ }^{1+} \mathrm{A}$ large prospective study has also shown no effect of previous use of the pill on cardiovascular disease. ${ }^{15}$

New "selective" progestogens (desogestrel, gestodene, and norgestimate) have been introduced in the past decade. These differ from their predecessors by having much less binding affinity for androgen receptors, ${ }^{16-19}$ which modifies their metabolic effects. In particular, there is no lowering of the high density lipoprotein cholesterol concentration, ${ }^{20-22}$ no insulin resistance, ${ }^{23}$ and the concentration of sex hormone binding globulin rises instead of falls. ${ }^{25}{ }^{26}$ These findings allow for optimism about the risk of cardiovascular disease in women taking such pills long term.

Whether women who begin taking the pill when young are at a greater risk of breast cancer by the age of 35 is still debated. ${ }^{27}{ }^{28}$ It is clear, however, that the risk does not increase for any duration of use up to the age of 45 , provided treatment is begun after the age of 25 . Several studies have shown an association between the pill and cancer of the cervix, but causation is not established as most studies have not adequately controlled for more established risk factors such as smoking and the sexual behaviour of both partners. Any cancer promoting effects are counterbalanced by the halving of the risks of endometrial and ovarian cancers. ${ }^{29}$
Trends in use of contraception among women aged 18-44 in Great Britain. Figures are percentages

\begin{tabular}{|c|c|c|c|c|}
\hline \multirow[b]{3}{*}{$\begin{array}{l}\text { Current usual method of } \\
\text { contraception }\end{array}$} & \multicolumn{4}{|c|}{ Survey } \\
\hline & \multirow[b]{2}{*}{$\begin{array}{l}\text { Family Formation } \\
\text { Survey } 1976\end{array}$} & \multicolumn{3}{|c|}{ General Household Survey } \\
\hline & & 1983 & 1986 & 1989 \\
\hline \multicolumn{5}{|l|}{ Non-surgical: } \\
\hline Pill & 29 & 28 & 26 & 25 \\
\hline Intrauterine device & 6 & 6 & 8 & 6 \\
\hline Condom & 14 & 13 & 13 & 16 \\
\hline Cap & 2 & 1 & 2 & 1 \\
\hline Withdrawal & 5 & 4 & 4 & 4 \\
\hline Safe period & 1 & 1 & 2 & 2 \\
\hline Other & 1 & 1 & 1 & 1 \\
\hline \multirow{2}{*}{\multicolumn{5}{|c|}{ Surgical: }} \\
\hline & & & & \\
\hline Female sterilisation & 7 & 11 & 11 & 11 \\
\hline Male sterilisation & 6 & 10 & 12 & 12 \\
\hline $\begin{array}{l}\text { Total using at least } \\
\text { one method }\end{array}$ & 68 & 75 & 75 & 72 \\
\hline
\end{tabular}

Source: Office of Population Censuses and Surveys.

The pill has other benefits. ${ }^{30}$ These range from fewer disorders of the menstrual cycle (such as dysmenorrhoea, menorrhagia, and the premenstrual syndrome) to almost complete protection against benign breast disease and benign ovarian cysts. In addition, the pill protects against pelvic inflammatory disease and ectopic pregnancy. ${ }^{30}$

A risk-benefit computer analysis of previously published data on the risks of cancer and cardiovascular disease compared women who used combined oral contraceptives or condoms from the age of 16 to 35 , each cohort then relying on sterilisation. ${ }^{13}$ By the age of 50 the women in the cohort taking the pill fared better or no worse than the cohort using condoms, according to almost all risk assumptions. Careful prescribing and monitoring should take into account established absolute and relative contraindications $\mathrm{s}^{31}{ }^{32}$ and the important influence of the regular pill free interval. ${ }^{33}$ Eliminating the pill free interval may be useful to obtain greater contraceptive efficacy or to avoid side effects if they are limited to that part in the cycle.

The progestogen only pill has suffered from the unfortunate label of "minipill," ${ }_{34}$ which has led to its confusion with low dose combined pills, limiting its perceived usefulness. The progestogen only pill may be used by women of any age for whom oestrogen is contraindicated. ${ }^{35}$ This makes it a suitable method for smokers at any age and women with hypertension, diabetes, or a history of cardiovascular disease. It is also valuable during lactation. Its main disadvantages are the menstrual irregularities that affect nearly half the women who take it and the need to take the pill at the same time every day (within three hours). Its failure rate decreases with age, being highest in women under 29 at about four per 100 woman years. ${ }^{36}$ Over the age of 35 the failure rate drops to one per 100 woman years. (A more recent study has suggested that the failure rate in young women may in fact be lower than that previously reported, with a rate among all ages, including the under $25 \mathrm{~s}$, of one per 100 woman years or less. ${ }^{37}$ ) 
A controversial method is progestogen by injection, the most widely used type being depomedroxyprogesterone acetate (Depo-Provera). Reports of an increased risk of breast cancer in beagle bitches and this method's early wide use in mainly Third World rather than developed countries led to a "Ban the Jab" movement that was so successful that the Food and Drug Administration has not yet licensed the drug. ${ }^{38}$ (Depo-Provera was granted a limited licence in the United Kingdom in 1984.) Depomedroxyprogesterone acetate is, however, an extremely effective (failure rate $<0.5$ per 100 woman years), ${ }^{38}$ reversible, ${ }^{39}$ and relatively safe method of contraception that deserves wider use. ${ }^{+0}$ In common with all progestogen only methods it can be used without an upper age limit in smokers and when oestrogen is contraindicated. Caution may be advisable in women at very high risk of arterial disease as in some (but not all) studies it was associated with a slight lowering of high density lipoprotein cholesterol concentration.

Other non-oral routes for progestogens either alone or in combination with oestrogen are likely to be used more in the next few years. These routes are particularly attractive as they should reduce metabolic and other side effects and simplify compliance. Methods include vaginal rings ${ }^{+1}$ and subcutaneous implants. The progestogen releasing vaginal ring is an effective and popular method, with a failure rate of approximately three to four per 100 woman years in a large multinational study. ${ }^{+2}$ The ring may be inserted and removed by the women and is designed to remain in place for three months. Side effects are similar to those of the progestogen only pill, menstrual irregularity being the most common reason for stopping treatment. The ring should be available for general use within the next year.

A subcutaneous progestogen only implant (Norplant) has recently been granted approval by the US Food and Drug Administration and is likely to become available in the United Kingdom within the next two years. It consists of six capsules containing levonorgestrel, which release an average of $30 \mu \mathrm{g}$ levonorgestrel each day for five years. As with the ring the main problem is menstrual irregularity. The failure rate is less than one per 100 women years, although the rate is twice this in women weighing over $70 \mathrm{~kg}$. This link with weight was also found with the ring ${ }^{42}$ and may apply to all progestogen only methods.

\section{Intrauterine devices}

The past 30 years have seen great fluctuations in the popularity of other methods of contraception. The inert and copper intrauterine devices, which were so popular in the 1960s and '70s, were all withdrawn for a time in the United States because of huge legal defence costs incurred by the manufacturers. ${ }^{+3}$ The Dalkon shield, which was associated with midtrimester septic abortion ${ }^{+4}$ and pelvic inflammatory disease,${ }^{45}$ was removed from the market in 1974. This led to a popular backlash against all intrauterine devices. Recently it has been realised that the risk of pelvic inflammatory disease is mainly related to how many sexual partners a woman (and her partner) have. If a couple are monogamous the risk of pelvic inflammatory disease may not be increased except in the first few months after insertion. ${ }^{+7-49} \mathrm{~A}$ copper intrauterine device may be left in place for at least five years ${ }^{50}$; any device fitted after the age of 40 may be safely left in place until the menopause. ${ }^{\text {I1 }}$

A new intrauterine device releasing levonorgestrel may also help to improve the popularity of this method. ${ }^{523}$ To the vertical limb of the well established Nova $T$ intrauterine device a Silastic capsule containing levonorgestrel has been added, which releases $20 \mu \mathrm{g}$ levonorgestrel daily for at least six years. Its failure rate is low-only 0.5 per 100 woman years $^{5+}$ - and, unlike its progesterone releasing predecessor, it is associated with a reduced risk of ectopic pregnancy; in addition, menstrual flow and dysmenorrhoea are less. ${ }^{5}$ This device, or variants using the new progestogens, may be ideal for women approaching or past the menopause as it improves menorrhagia, provides contraception, protects against endometrial hyperstimulation, and may prevent endometrial cancer during hormone replacement therapy. ${ }^{56}$

\section{Barrier methods}

With the threat of AIDS and other sexually transmitted diseases barrier methods have come back into fashion: the actual failure rates of barrier methods (particularly among young people) are often considerably higher (between 10 and 15 per 100 woman years ${ }^{57}$ ) than their theoretical ones. ${ }^{58}$ This has led to the suggestion that women entering a new relationship should use the sheath as protection against infection but take the pill (or use another reliable method) for contraception. ${ }^{59}$ Studies are beginning to show that regular use of condoms helps prevent the spread of HIV, ${ }^{6061}$ and this needs communicating to patients.

Whether spermicides are necessary for the effectiveness of the diaphragm is not known, although studies are under way. ${ }^{62}$ In vitro studies have shown, however, that in sufficiently high concentrations $(>5 \%)$ nonoxinol 9 can inactivate $\mathrm{HIV},{ }^{63-65}$ although the efficacy of nonoxinol 9 against intracellular virus has been questioned. ${ }^{66}$ It has recently been suggested that very frequent use of nonoxinol 9 (150 $\mathrm{mg}$ four times daily for two weeks) may disrupt the vaginal and cervical epithelium, ${ }^{67}$ which could be relevant to the transmission of HIV.

The female condom is a plastic pouch inserted as a lining to the whole vaginal surface. Intercourse takes place within it, aided by a lubricant. At its rim an integral lower (vulvar) ring prevents the condom from being dislodged into the vagina, and an upper loose ring aids retention. Early studies have been reasonably encouraging, ${ }^{68}$ but more data are still needed on its effectiveness and acceptability.

\section{Other methods}

Sterilisation, both male and female, continues to increase in popularity and has replaced the contraceptive pill as the most widely used method of birth control among couples when the woman is over $30 .^{69}$ Applying clips at laparoscopy under general or local anaesthesia is now generally preferred for women. ${ }^{7071}$ The technique of "no scalpel vasectomy" (performed through a one millimetre puncture produced by sharp forceps) has been pioneered in the Far East, particularly China and Thailand, and seems to be an even quicker method, with fewer complications than conventional vasectomy. ${ }^{72}$

The "male pill" remains elusive. The problems associated with its development are the large numbers of sperm produced, the three month "lag" period until all those already produced have been eliminated, the possibility of future sperm being abnormal, and, not least, the problem of maintaining male libido at the same time as contraception. ${ }^{73} \mathrm{~A}$ recent study of regular injections of testosterone ${ }^{74}$ gave renewed hope of progress, although for the idea to become more widely acceptable the weekly injections will need replacing by a longer acting dose.

Immunological methods are likely to become available only in the more distant future, in particular contraceptive vaccines, which have the potential to be cheap, convenient, long acting, and reversible, with few side effects. The most promising of these so far has been the antihuman chorionic gonadotrophin vaccine developed by the World Health Organisation. ${ }^{75}$ This has reached the stage of phase II clinical trials. An antizona 
pellucida vaccine is under study in Edinburgh but has not yet been tested in humans.

What will happen during the next 30 years? Every year this decade 90 million more humans will live on the planet. An important cause of this is the continuing unavailability of methods of birth control in rural and slum areas. There is, however, a disappointingly high number of unplanned pregnancies even where the present methods are available. This has much to do with perceived side effects and "nuisance value," both of which adversely affect motivation. We believe that the contraceptive pill will continue in use, substantially in its present form, until well into the next century. But the need

1 Dicfalusy E. Gregory Pincus and steroidal contraception revisited. Acta Obstet Gynecol Scand $1982 ; 105$ (suppl): $7-15$

2 Office of Population Censuses and Surveys. General Houschold Survey 1989. OPCS Monitor 1990;3:13-4. (SS 90/3.)

3 Jordan WM. Pulmonary embolism. Lancet 1961;ii:1146-7.

4 Inman WHW, Vessey MP, Westerholm B, Engelund A. Thrombo-embolic disease and the steroidal content of oral contraceptives. A report to the Committee on Safety of Drugs. $B M \mathcal{Y}$ 1970;ii:203-9.

5 Mammen EF. Orat 1982;142:781-90.

Colle of General Practioners oral contraception study: some recent observations. Clin Obstet Gynecol 1984;11:759-86.

7 Sachs BP, Masterson T, Jewett JF, Guyer B. Reproductive mortality in Massachusetts in 1981. N Engl F Med 1985;311:667-70.

8 Layde PM, Ory HW, Schlesselman JJ. The risk of myocardial infarction in former users of oral contraceptives. International Family Planning Perspectives 1982;2:79-81.

9 Vessey MP. Female hormones and vascular disease -an epidemiological overview. British fournal of Family Planning 1980;6 (suppl):1-12.

10 Mann JI, Inman WHW. Oral contraceptives and death from myocardial infarction. BMF 1975;ii:245-8.

11 Kay C. Present perspectives and clinical implications. $\mathcal{F}$ Obstet Gynecol 1984;4 (suppl):98-102.

12 Croft P, Hannaford PC. Risk factors for acute myocardial infarction in women: evidence from the Royal College of General Practitioners oral contraception study. BMF 1989;298: 165-8.

13 Vessey MP, Villard-Mackintosh L, McPherson K, Yeates D. Mortality among oral contraceptive users: 20 year follow up of women in a cohort study. BMF 1989;299:1487-91.

14 Fortney JA. Oral contraceptives for older women. IPPF Medical Bulletin 1990;24:3-4

15 Stampfer MJ, Willett WC, Colditz GA, Speizer FE, Hennekens CH. A prospective study of past use of oral contraceptive agents and risk of cardiovascular diseases. $N$ Engl f Med 1988;19: use of oral. $1313-7$.

16 Rekers H. New generation of monophasic oral contraceptives. In: Keller PJ, ed. Contraception into the next decade. Carnforth: Parthenon, 1988:13-24

17 Elgar W, Steinbeck J, Schillinger E, Losert W, Brier S. Endocrine pharmacological profile of gestodene. Advances in contraceptive delivery systems II 1986:2:182-97.

18 Gillmer MDG. Metabolic effects of combined oral contraceptives. In: Filshie M, Guillebaud J, eds. Contraception: science and practice. London: Butterworths, 1989:11-38.

19 Kloosterboer HJ, Vonk-Noordegraff CA, Turpiin EW. Selectivity of progesterone and androgen receptor binding of progestogens used in oral contraceptives. Contraception 1988;38:325-32.

20 Lepot MR, Gaspard UJ. Metabolic effects of two low dose triphasic oral contraceptives containing ethinyloestradiol and levonorgestrel or gestodene. Int $\mathcal{F}$ Fertil 1987;32 (suppl):15-20.

21 Tikkanen MJ, Nikkila EA. Oral contraceptives and lipoprotein metabolism. fournal of Reproductive Medicine 1986;31 (suppl 9):898-905.

22 Godsland IF, Crook D, Simpson R, et al. The effects of different formulations of oral contraceptive agents on lipid and carbohydrate metabolism. N Engl F Med 1990;323:1375-81.

agents on lipid and carbohydrate metabolism. N Engl $\mathcal{F}$ Med 1990;323:1375-81.
Rabe T, Runnebaum B, Kohlmeier T, et al. Clinical and metabolic effects of gestodene and levonorgestrel. Int $\mathcal{F}$ Fertil 1987;32 (suppl):29-44.

24 Van der Vange N, Kloosterboer HJ, Haspels AA. Effect of seven low dose combined oral contraceptive preparations on carbohydrate metabolism. Am f Obstet Gynecol 1987;156: 918-22.

25 Hammond G, Langley MS, Robinson PA, et al. Serum steroid binding protein concentrations, distribution of progestogens and bioavailability of testosterone during treatment with contraceptives containing desogestrel or levonorgestrel. Fertil Steril 1984;42:44-51.

26 Fotherby K, Trayner I, Longhorne PN, et al. Metabolic investigations with Femodene-an oral contraceptive containing gestodene and ethinyloestradiol. Contraception 1987;35:323-37.

27 Cancer and Steroid Hormones Study. Oral contraceptive use and the risk of breast cancer. N Engl $\mathcal{F}$ Med 1986;315:415-21.

28 Mann RD, ed. Oral contraceptives and breast cancer. Carnforth: Parthenon, 1990.

29 Vessey MP. Oral contraception and cancer. In: Filshie M, Guillebaud J, eds. Contraception: science and practice. London: Butterworths, 1989:52-69.

30 Drife J. The benefits of combined oral contraceptives. Br f Obstet Gynaecol 1989;96:1255-60.

31 Guillebaud J. Oral contraceptives in risk groups: exclusion or monitoring. Am $\mathcal{F}$ Obstet Gynecol $1990 ; 163$ (suppl):443-6.

32 Guillebaud J. Practical prescribing of the combined oral contraceptive pill. In: Filshie $M$, Guillebaud J, eds. Contraception: science and practice. London: Butterworths, 1989:69-93.

33 Guillebaud J. The forgotten pill-and the paramount importance of the pill free week. British fournal of Family Planning 1987;12 (suppl):35-43.

34 Rinehart W. The minipill - a limited alternative for certain women. Pop Reps 1975;3:A53-A67.

35 Fotherby K. The progestogen only pill. In: Filshie M, Guillebaud J, eds. Contraception: science and practice. London: Butterworths, 1989:94-109.

36 Vessey MP, Lawless M, Yeates D, et al. Progestogen only oral contraception. Findings in a large prospective study with special reference to effectiveness. British fournal of Family Planning 1985;10:117-21.

37 Bisset AM, Dingwall-Fordyce I, Hamilton MIK. The efficacy of the progestogen only pill as a contraceptive method. British foumal of Family Planning 1990;16:84-8.

38 Fraser IS. Long acting hormonal contraceptives. In: Shearman RP, ed. Clinical reproductive endocrinology. Edinburgh/London: Churchill Livingstone, 1985:634-55.

39 Pardthaisong T, Gray RH, McDaniel EB. Return of fertility after discontinuation of depot for new methods of contraception is also great, far greater than the resources devoted to research would suggest. The need for protection against sexually transmitted diseases is also likely to stimulate much needed improvements in barriers, spermicides, and virucides.

Senior Clinical Medical Officer in Family Planning

ANNE SZAREWSKI

Medical Director

Margaret Pyke Centre,

London WIV 5TW

For details of emergency contraception see BMF 1991;302:801.

medroxyprogestogen acetate and intrauterine devices in northern Thailand. Lancet 1980; 509-11.

40 Fraser IS. Systemic hormonal contraception by non-oral routes. In: Filshie M, Guillebaud J, eds. Contraception: science and practice. London: Butterworths, 1989:109-26.

41 Population Reports. Hormonal contraception: new long-acting methods. Baltimore: Population Information Programs, Johns Hopkins University, 1987. (Series K No 3.)

42 World Health Organisation Task Force on Long-acting Systemic Agents for Fertility Regulation. Microdose intravaginal levonorgestrel contraception: a multicentre clinical trial: 1. Contraceptive efficacy and side effects. 2. Expulsions and removals. 3. The relationship between pregnancy rate efficacy and side effects. 2 . Expulsions and removals. 3. The relationsh

43 Sapire EK. Intrauterine contraceptive devices. In: Contraception and sexuality in health and disease. London: McGraw Hill, 1990:179-231.

44 Christian CD. Maternal deaths associated with an intrauterine device. Am $\mathcal{F}$ Obstet Gynecol 1974;119:441-4.

45 Lee NC. Type of intrauterine device and the risk of pelvic inflammatory disease. Obstet Gynecol 1983;62:1-6.

46 Buchan H, Villard-Mackintosh L, Vessey M, Yeates D, McPherson K. Epidemiology of pelvic inflammatory disease in women with special reference to intrauterine device. $\mathrm{Br} \mathcal{J}$ Obste Gynaecol 1990;97:780-8.

47 Lee NC, Rubin GL, Ory HW, Burkman RT. The intrauterine device and pelvic inflammatory disease: new results from the Women's Health Study. Obstet Gynecol 1988;72:1-6.

48 Daling JR, Weiss NS, Metch BJ, et al. Primary tubal infertility in relation to the use of an intrauterine device. $N$ Engl f Med 1985;312:937-41.

49 Cramer DW, Schiff T, Schoenbaum SC. Tubal infertility and the intrauterine device. $N$ Engl $f$ Med 1985;312:941-7.

50 Newton J, Tacchi D. Long term use of copper intrauterine devices. Lancet 1990;335:1322-3.

51 Tacchi D. Long term use of copper intrauterine devices. Lancet 1990;335:182.

52 Sivin I, Stern J, Diaz J, et al. Two years of intrauterine contraception with levonorgestrel and with copper: a randomised comparison of the TCu $380 \mathrm{Ag}$ and levonorgestrel $20 \mathrm{mcg} / \mathrm{day}$ devices. Contraception 1987;35:245-55.

53 World Health Organisation Scientific Group. Mechanism of action, safety and efficacy of intrauterine devices. Geneva: WHO, 1987. (WHO Technical Report Series 753.)

54 Odlind V. Hormonal long-acting methods for contraception. British fournal of Family Planning 1991;16(suppl):8-11.

55 Andersson JK, Rybo G. Levonorgestrel-releasing intrauterine device in the treatment of menorrhagia. Br f Obstet Gynaecol 1990;97:690-4.

56 Bowen-Simpkins P. Contraception for the older woman. In: Filshie M, Guillebaud J, eds Contraception: science and practice. London: Butterworths, 1989:224-39.

57 Vessey MP, Villard-Mackintosh I, McPherson K, Yeates D. Factors affecting use-effectiveness of the condom. British fournal of Family Planning 1988;14:40-3.

58 Vessey MP, Lawless M, Yeates D. Efficacy of different contraceptive methods. Lancet 1982;ii: $841-2$.

59 Bounds W. Male and female barrier contraceptive methods. In: Filshie M, Guillebaud J, eds. Contraception: science and practice. London: Butterworths, 1989:172-203.

60 Fischl M, Dickinson GM, Scott GB, et al. Evaluation of heterosexual partners, children, and household contacts of adults with AIDS. FAMA 1987;257:640.

61 Smith GL, Smith KF. Lack of HIV infection and condom use in licensed prostitutes. Lancet 1986;ii:1392.

62 Craig S, Hepburn S. The effectiveness of barrier methods of contraception with and without spermicide. Contraception 1982;26:347-59.

63 Hicks DR, Martin LS, Getchell JP, et al. Inactivation of HTLV III/LAV infected cultures of normal human lymphocytes by nonoxynol 9 in vitro. Lancet 1985;ii: 1422-3.

64 Malkovsky M, Newell A, Dalgleish AG. Inactivation of HIV by nonoxynol 9. Lancet 1988;i:645.

65 Rietmeijer CAM, Krebs JW, Feorino PM, Judson FN. Condoms as physical and chemical barriers against human immunodeficiency virus. $\mathcal{F} A M A$ 1988;259:1851-3.

66 Trap R, Trap B, Petersen CS. Evaluation of the amount of nonoxynol available in condoms for the inhibition of HIV using a method based on HPLC. International foumal of Sexually Transmitted Diseases and AIDS 1990;1:346-9.

67 Niruthisard S, Roddy R, Chutivongse S. The effects of frequent nonxynol 9 use on the vaginal and cervical mucosa. Sexually Transmitted Diseases (in press).

68 Bounds W, Guillebaud J, Stewart L, Steel S. A female condom (Femshield). A pilot study of its user acceptability. British fournal of Family Planning 1988;14:83-8.

69 Office of Population Censuses and Surveys. General Household Survey 1987. London: OPCS, 1987:50-5. (Series GHS17.)

70 Mackenzie IZ, Turner E, O'Sullivan GM, Guillebaud J. Two hundred outpatient laparoscopy slip sterilisations using local anaesthesia. Br f Obstet Gynaecol 1987;94:449-53.

71 Rioux JE. Female sterilisation and its reversal. In: Filshie M, Guillebaud J, eds. Contraception science and practice. London: Butterworths, 1989:275-91.

72 Nirapathpongporn A, Huber DH, Krieger JN. No-scalpel vasectomy at the King's birthday vasectomy festival. Lancet 1990;335:894-5.

73 Population Reports. Men-new focus for family planning programs. Baltimore: Population Information Programs, Johns Hopkins University, 1986. (Series J No 33.)

74 WHO Task Force on Methods for the Regulation of Male Fertility. Contraceptive efficacy of restosterone - induced azoospermia in normal men. Lancet 1990;336:955-9.

75 Jones WR, Bradley J, Judd SJ, et al. Phase 1 clinical trial of the WHO birth control vaccine. Lancet 1988 ;i:1295-8. 